\title{
PENDAMPINGAN PEMBELAJARAN MATEMATIKA DENGAN MEDIA DORATIC TERHADAP SISWA PENYANDANG DISSABILITAS TUNA GRAHITA
}

\author{
Achmad Hidayatullah ${ }^{1}$, Amirul Latif $^{2}$, Dewi Herawati ${ }^{3}$ \\ ${ }^{1}$ Prodi Pendidikan Matematika FKIP UMSurabaya \\ ${ }^{2}$ Prodi Pendidikan Matematika FKIP UMSurabaya \\ ${ }^{3}$ Prodi Pendidikan Matematika FKIP UMSurabaya
}

achmad.pendmat@fkip.um-surabaya.ac.id ${ }^{1}$, amirul.latif06@gmail.com², dewihera47@gmail.com ${ }^{3}$

\begin{abstract}
Abstrak
Pengabdian ini berupa pendampingan pembelajaran matematika dengan media Doratic (Doll Train Mathematics) terhadap anak penyandang dissabilitas tuna grahita di Yayasan Pendidikan Luar Biasa Alpa Kumara Wardhana Surabaya. Pelaksanaan pengabdian dimulai dengan pembuatan media doratic berbentuk boneka kereta bangun ruang yang terdiri dari kubus, balok, kerucut, tabung, limas segitiga dan limas segiempat. Hasil dari pengabdian ini diperoleh dari observasi terhadap aktivitas siswa, respon siswa dan hasil post tes yang dilakukan dua kali. Berdasarkan aktivitas siswa, mereka dominan dalam bermain dengan menggunakan Doratic dengan prosesntase $30 \%$, sedangkan respon siswa 47,5\%, siswa menjawab setuju (S) 46,3\%, siswa menjawab tidak setuju (TS) 6,3\%. Sehingga disimpulkan Media ini sangat menarik dan mendukung proses belajar siswa. Hasil post test menunjukkan adanya peningkatan hasil pembelajaran siswa sehingga mencapai kriteria ketuntasan minimal. Sebanyak $90,48 \%$ siswa yang tuntas belajar dan sebanyak 9,52\% siswa tidak tuntas belajar. Nilai rata-rata pada pertemuan ke 3 adalah 76,14.
\end{abstract}

Kata Kunci: Doratic, Pembelajaran, Matematik 


\section{PENDAHULUAN}

Anak yang Berkebutuhan Khusus (ABK) merupakan istilah lain untuk menggantikan kata Anak Luar Biasa (ALB) yang menandakan adanya kelainan khusus yang memiliki karakteristik berbeda antara satu dengan yang lainnya. Anak Tunagrahita merupakan salah satu anak berkebutuhan khusus yang memiliki gangguan perkembangan mentalnya yang disebabkan karena rendahnya tingkat kecerdasan. Salah satu cara pengembangan potensi diri dalam masalah pedidikan sekaligus sebagai sarana pembelajaran matematika pada materi bangun datar dan bangun ruang. Matematika adalah ilmu yang bersifat abstrak dan anak tunagrahita sering mengalami kesulitan dalam memahami sesuatu yang bersifat abstrak. Oleh karena itu proses pembelajaran harus diberikan dalam bentuk konkrit, sehingga digunakan benda-benda yang bersifat nyata dan diimbangi dengan metode yang menyenangkan yaitu dengan metode bermain sambil belajar. Dengan bermain, anak tunagrahita dapat belajar dan mengerjakan tugas yang diberikan dengan senang hati tanpa ada beban. Bermain adalah dunia anak, dimanapun anak-anak berada dan di waktu apapun, bermain adalah aktivitas utama mereka. melalui bermain, anak-anak dapat mengekspresikan apapun yang mereka inginkan. (Hasdianah : 2013).

Berdasarkan Badan Pusat Statistik (BPS) tahun 2012, jumlah Persentase Penyandang Difabel Menurut Jenis Gangguan yang Dialami di Jawa Timur, Tahun 2012 Mempunyai Gangguan Berat (Disabilitas) terdapat $87 \%$ sekitar 332.069 anak. Pada Yayasan Pendidikan Luar Biasa Alpa Kumara Wardhana terletak di jalan Kalibokor Timur 165, Surabaya jumlah siswa penyandang tunagrahita tahun 2017 terdapat kurang lebih
100 siswa. Dari permasalahan di atas kami mempunyai solusi dengan menggunakan media pembelajaran DORATIC ini. Media ini disediakan untuk anak berkebutuhan khusus seperti anak Tunagrahita. Karena mereka juga membutuhkan sarana pengembangan potensi sekaligus sebagai sarana pembelajaran.

Melihat dari realita yang ada sehingga diperlukan adanya media pembelajaran DORATIC yang tidak hanya dapat digunakan oleh anak normal tetapi juga dapat digunakan oleh anak berkebutuhan khusus. DORATIC merupakan kependekan dari doll train mathematic yang dapat diartikan sebagai kereta api boneka matematika, DORATIC merupakan media berbasis audio visual yang digunakan untuk anak penyandang tunagrahita, media yang didesain dengan sedemikian rupa sehingga menarik dan menyenangkan untuk anak dengan model seperti halnya kereta api Thomas yang disukai anak-anak pada umumnya dengan tambahan pengeras suara yang bertujuan agar anak lebih mudah memahami materi bangun datar dan bangun ruang. Cara anak tunagrahita menggunakan DORATIC cukup dengan menyimak audio dan melihat bangun yang ada pada DORATIC dimana mereka akan lebih mudah mempelajari matematika pada materi bangun datar dan bangun ruang sambil bermain. Oleh karena itu diharapkan pengabdian kepada masyarakat ini dapat membantu masyarakat Yayasan khususnya siswa-siswi penyandang tungrahita melalui penerapan media pembelajaran DORATIC guna peningkatan dan pengembangan potensi diri dalam masalah pedidikan sehingga penerapan media pembelajaran DORATIC dapat menghasilkan siswa-siswi Yayasan yang terampil, berpotensi, dan mengembangkan daya kreatifitas pada anak tunagrahita. 
Yayasan Pendidikan Luar Biasa Alpa Kumara Wardhana terletak di jalan Kalibokor Timur 165, Surabaya 60282, Jawa Timur. Sasaran media pembelajaran ini adalah siswa dan siswi Yayasan Pendidikan Luar Biasa Alpa Kumara Wardhana yang menjadi masyarakat yayasan sebagai objek dalam penerapan media pembelajaran DORATIC. Melalui pengabdian yayasan ini diharapkan siswa-siswi Yayasan Pendidikan Luar Biasa Alpa Kumara Wardhana dapat mengerti tentang materi bangun datar dan bangun ruang.

Potensi di Yayasan Pendidikan Luar Biasa Alpa Kumara Wardhana untuk dijadikan tempat penerapan media DORATIC ini sangat baik karena media pembelajaran ini dapat meningkatkan kognitif atau pengetahuan anak tunagrahita untuk mengenal bentuk bangun ruang yang ada di sekitar lingkungannya (sekolah, keluarga, dan masyarakat).

\section{METODE PENELITIAN}

Metodepelaksanaan yang akan dikembangkan di susun secara sistematis melalui tahapan berikut:

\section{Menetapkan Daerah Sasaran}

Pada tanggal 01 November 2017 kami menetapkan daerah sasaran di Yayasan Pendidikan Luar Biasa Alpa Kumara Wardhana, Surabaya.

2. Survei Yayasan Sasaran

Meninjau lokasi Yayaysan SLB di daerah Surabaya, Yayasan yang kita ajukan kerjasama dalam penerapan media pembelajaran DORATIC di Yayasan Pendidikan Luar Biasa Alpa Kumara Wardhana, Surabaya. Serta memahami kondisi sosial di Yayasan tersebut.

3. Melakukan observasi yayasan yang telah disepakati

Kegiatan pengamatan dilaksanakan pada bulan November 2017 tanggal 03 di Yayasan Pendidikan Luar Alpa Kumara Wardhana di jalan Kalibokor Timur 165, Surabaya, lalu kami melakukan observasi terhadap anak - anak Tunagrahita baik melalui secara melihat langsung dan juga memperoleh informasi dari pihak kepala sekolah.

4. Memohon perizinan untuk melakasanakan penerapan media pembelajaran

Pada tanggal 03 November 2017 tim mengajukan memohon perizinan untuk pelaksanaan pengabdian dalam hal pembelajaraan menggunakan media pembelajaran DORATIC di Yayasan Pendidikan Luar Alpa Kumara Wardhana ,di jalan Kalibokor Timur 165 Surabaya. Perizinan tertulis di dalam Surat Pernyataan Kesediaan dari Mitra Usaha dalam Pelaksanaan Program Kreativitas Mahasiswa.

5. Menentukan jadwal penerapan media pembelajaran

Penentuan jadwal penerapan dilakukan pada tanggal 07 Mei 2018, dengan menemui kepala sekolah, dalam penentuan jadwal kami diberi waktu 3 hari yaitu pada tanggal 24 - 
26 Mei 2018, dikarenakan sebelum tanggal tersebut masih ada kegiatan Ujian Akhir Sekolah dan setelah tanggal tersebut pihak Yayasan sudah mulai libur panjang. Sehingga tim mendiskusikan terkait tindak lanjut pengabdian media DORATIC, dengan dosen pembimbing sehingga menghasilkan keputusan dalam melanjutkan penerapan di rumah murid - murid Tunagrahita.

6. Menyusun media pembelajaran

Penyusunan media pembelajaran dilaksanakan mulai tanggal 14 April 2018-24 Mei dimulai dari pembelian bahan - bahan yang digunakan, sampai proses pembuatan media DORATIC menjadi boneka bangun ruang yang didesain sedemikian rupa dengan bentuk seperti kereta api, media bangun ruang yang dibuat diantaranya berbentuk Tabung, Kubus, Balok, Kerucut, Limas dan Prisma dengan di tambahi puzzle bangun datar pada setiap bangun ruang dan yang terakhir pemasangan alat suara pada bangun ruang yang di tempatkan sebaik mungkin demi kenyamanan bagi anak - anak Tunagrahita.

7. Penerapan media pembelajaran di Yayasan Pendidikan Luar Biasa Alpa Kumara Wardhana Mahasiswa Universitas Muhammadiyah Surabaya melakukan kegiatan pengabdian kepada masyarakat dengan menerapkan DORATIC kepada anak - anak Yayasan Alpa Kumara Wardhana, kegiatan ini dilakukan di kelas selama beberapa pertemuan. Para siswa yang hadir merupakan siswa Yayasan Alpa Kumara Wardhana. Jumlah siswa yang mengikuti pembelajaran matematika kurang lebih 30 orang. Awal kegiatan dimulai dengan pengenalan dari para mahasiswa.Serta para siswa diberikan pre test dengan cara bertanya kepada para siswa tentang materi bangun datar dan bangun ruang.Sebagian besar siswa mengalami kesulitan dalam menjawab pertanyaan yang diberikan . Selanjutnya para siswa belajar materi bangun datar dan bangun ruang dengan menggunakan media DORATIC. Siswa diminta untuk maju ke depan untuk menjelaskan di depan teman-teman nya tentang bangun datar dan bangun ruang. Pembimbing mengadakan kegiatan tanya jawab setelah penjelasan bangun datar dan bangun ruang dengan menggunakan media DORATIC, siswa menjadi lebih mudah memahami serta membedakan bangun datar dan bangun ruang. Kegiatan dilanjutkan dengan post test, siswa diberikan LKS dan diminta untuk menjawab pertanyaan yang ada.

\section{Evaluasi}

Evaluasi dilakukan setelah proses pembelajaran dilaksanakan, mengenai 
ketercapaian indikator keberhasilan. Evaluasi dilihat dari pre test(sebelum diberikan media) dan post test (setelah diberikan media).

Evaluasi dari kegiatan pengabdian masyarakat ini terdiri atas sasaran, indikator keberhasilan, dan kendala. Sasaran kegiatan pengabdian masyarakat ini adalah

- Memberikan pengalaman pada siswa Yayayasan Alpa Kumara Wardhana dalam pembelajaran pada materi bangun datar dan bangun ruang dengan media DORATIC.

Siswa yang dirasa mampu dan unggul pada saat pembelajaran, dijadikan sebagai kader yang akan menindaklanjuti pelaksaanan pengabdian masyarakat kepada siswa Yayasan Alpa Kumara Wardhana.

Indikator keberhasilan kegiatan pengabdian masyarakat ini adalah

- Siswa dapat belajar matematika dengan lebih aktif

- Siswa belajar dengan lebih menyenangkan

\section{Pembentukan Duta DORATIC}

Duta DORATIC dibentuk dengan melihat hasil pre test dan pos test yang sudah memenuhi target ketercapaian. Duta DORATIC terdiri dari dua orang laki- laki yaitu Adifdan Vido. Dengan cara duta yang dipilih diminta mengajarkan dan menerapkan media DORATIC di depan temanteman lainnya dengan arahan dari pembimbing

\section{HASIL DAN PEMBAHASAN}

Sebelum kegiatan kami melakukan pemantapan kegiatan dengan kerjasama pihak sekolah, guru dan meminta pasukan para pakar sehingga pelaksanaan kegiatan kami berjalan maksimal. Konsep pengabdian ini adalah pendampingan pembelajaran dengan membuat media pembelajaran audio visual untuk penyandang tunagrahita. Program ini dilaksanakan efektif mulai bulan April hingga Juli 2018.

\section{Pembuatan Produk Doratic}

Tahapan pertama dalam pengabdian ini adalah pembuatan produk media pembelajaran untuk tunagrahita yang dihasilkan pada tanggal 24 Mei 2018. Media pembelajaran doratic ini dibuat dengan menggunakan bahanbahan yang mudah didapatkan dan halus. Pemilihan bahan tersebut dimaksudkan agar tidak berbahaya untuk anak-anak terhadap penyandang tunagrahita. Pemilihan desain dari produk, mengadopsi bentuk kereta api agar lebih menyenangkan terhadap siswa, tujuannya agar ada integrasi antara pembelajaran di kelas dengan kehidupan siswa. Dengan demikian siswa memiliki imajinasi tentang kaitan pembelajaran matematika dengan kehidupan siswa. Desain doratic sebelumnya dibuat dalam bentuk gambar untuk mempermudah pembuatan.

Doratic dilengkapi dengan soundsystem yang memiliki suara berupa music dan keterangan tentang bangun ruang masing-masing bagian kereta api. Setiap sisi dari bagian dari kreta memiliki keterangan rumus luas dan volume. Adapun bagian dari kereta diantaranya, balok, kubus, limas segitiga, limas segiempat, kerucut dan tabung. 
Gambar 1. Tampilan Media Doratic

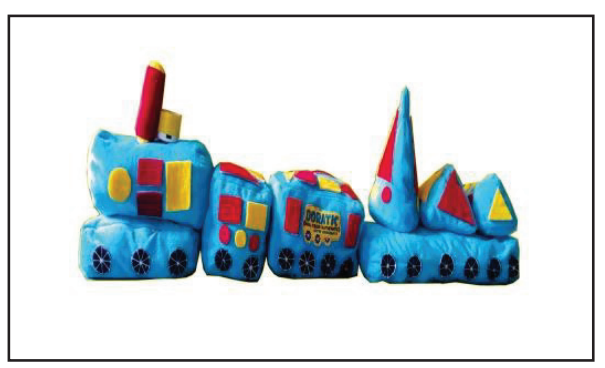

\section{Pembuatan Pedoman Penggunaan Media Doratic}

Tahapan selanjutnya adalah membuat buku panduan penggunaan media. Untuk mempermudah penggunaan media ini, maka kami juga membuat buku panduan.

\section{Ketercapaian Pembelajaran (Aktivitas, respond an hasil post test)}

Pada tahapan ini dilakukan pengabdian terhadap siswa penyandang tunagrahita mulai tanggal 25 - 26 Mei 2018 dan 9 ,11 Juni 2018. Data ketercapaian pelaksanaan kegiatan dalam pembelajaran diperoleh dari observasi terhadap siswa dan respon dari siswa. Selain itu untuk memperkuat data kami gunakan wawancara terhadap siswa.

Aktivitas siswa akan dianalisis dengan cara menghitung berapa persentase siswa selama proses penelitian.

a. Aktivitas siswa "Mendengarkan atau memperhatikan penjelasan guru" memperoleh hasil prosentase $19,1 \%$.

b. Aktivitas siswa "Diskusi dan tanya jawab antar siswa dan guru" memperoleh hasil prosentase $22,6 \%$.

c. Aktivitas siswa "bermain menggunakan doratic $30 \%$. d. Aktivitas siswa "Mendengarkan temannya yang lain saat bermain" memperoleh hasil prosentase $16 \%$.

e. Aktivitas siswa "Bertanya pada teman jika tidak mengerti" memperoleh hasil prosentase $9 \%$.

f. Aktivitas siswa "prilaku tidak relevan" memperoleh hasil prosentase $5,7 \%$.

Berdasarkan analisis data aktivitas siswa di atas dapat disimpulkan bahwa aktivitas siswa yang dominan dilakukan adalah aktivitas bermain menggunakan media doratic yaitu $30 \%$.

Respon siswa terhadap pembelajaran dengan medi Doratic ini dikumpulkan melalui instrument. Pada angket respon siswa ini di bagi menjadi 2 kategori yaitu respon positif dan respon negatif. Kategori positif didapatkan jika persentase siswa menjawab sangat setuju (SS) dan setuju (S) lebih besar dari pada persentase siswa yang menjawab tidak setuju (TS) dan sangat tidak setuju (STS), sebaliknya kategori negatif didapatkan jika persentase siswa menjawab tidak setuju (TS) dan sangat tidak setuju (STS) lebih besar dari pada persentase siswa yang menjawab sangat setuju (SS) dan setuju (S).

Data yang diperoleh bahwa siswa menjawab sangat setuju (SS) sebanyak 47,5\%, siswa menjawab setuju (S) 46,3\%, siswa menjawab tidak setuju (TS) 6,3\%, dan tidak ada siswa yang menjawab sangat tidak setuju (STS).

Berdasarkan hasil persentase di atas maka dapat disimpulkan bahwa pembelajaran matematika menggunakan media doratic adalah menarik dan disukai oleh siswa. 


\section{Refleksi pelaksanaan}

Refleksi dilakukan bertujuan untuk mengevaluasi proses pembelajaran yang terancang pada setiap pertemuan. Berdasarkan hasil pre tes pada pertemuan ke 1 yang diikuti 21 siswa atau seluruh siswa. Hasilnya sebanyak $61,91 \%$ siswa yang tuntas belajar dan sebanyak $38,09 \%$ siswa tidak tuntas belajar. Nilai ratarata pertemuan ke 3 adalah 66,48. Kemampuan siswa dikatakan meningkat bila banyaknya siswa yang mencapai $\mathrm{KKM} \geq 75 \%$.

Berdasarkan hasil observasi aktivitas siswa pada proses pembelajaran pertemuan 1-2, yang diamati oleh dua observer. Terdapat beberapa faktor yang mempengaruhi hasil tes siswa pada pertemuan ke 3 yaitu terdapat beberapa siswa yang kurang aktif dalam pembelajaran dan sering melakukan prilaku tidak relevan seperti tidak mendengarkan penjelasan guru, mengobrol sendiri-sendiri dan lainnya. Karena indikator keberhasilan belum tercapai maka dilakukan perbaikan pada pertemuan berikutnya.

Refleksi pada pertemuan ke 3 bertujuan untuk mengevaluasi proses pembelajaran yang terancang pada pertemuan ke 4-5. Berdasarkan hasil tes pertemuan ke 3 yang diikuti 21 siswa atau seluruh siswa. Hasilnya sebanyak 90,48\% siswa yang tuntas belajar dan sebanyak 9,52\% siswa tidak tuntas belajar. Nilai rata-rata pada pertemuan ke 3 adalah 76,14. Kemampuan siswa dikatakan meningkat bila banyaknya siswa yang mencapai $\mathrm{KKM} \geq 75 \%$.

\section{KESIMPULAN}

Pengabdian ini berupa pendampingan pembelajaran terhadap penyandang dissabilitas tunagrahita. Berdasarkan hasil pengabdian ini dihasilkan tiga pencapaian. Pertama produk media pembelajaran doratic atau doll train mathematics. Media ini diciptakan khusus untuk membantu siswa tunagrahita belajar matematika dengan cara bermain dan menyenangkan. Pencapaian kedua adalah pembuatan buku petunjuk penggunaan media ataubuku panduan. Ketiga, pencapaian aktivitas dan hasil posttest yang dikaji dalam bentuk relfeksi. Dari hasil observasi terhadap kegiatan ssiswa selama proses kegiatan ini didapatkan data bahwa siswa banyak beraktivitas dalam bermain dan belajar matematika dengan media doratic tersebut. Sedangkan berdasarkan hasil pretest dan post test pada pertemuan ke 1 dan 3 didapatkan data bahwa siswa mengalami peningkatan dalam pemahaman matematika dari pretest pertemuan ke 1 dan post test pertemuan ke 3. Pada pertemuan ke 3 didapatkan hasil siswa mencapai kriteria ketuntasan minimal dalam pembalajaran.

\section{DAFTAR PUSTKA}

(n.d.). Retrieved from http://www.bps.go.id.

(2017). In Pedoman PKM 2017. Jakarta: http:// simbelmawa.ristekdikti.go.id.

Erawati, I. L. (2016). Pendidikan Karakter Bangsa Pada Anak Berkebutuhan Khusus dalam Inklusi. Jurnal Studi Sosial, 22.

Hasdianah. (2013). In Autispada anak (Pencegahan, perawatan, dan pengobatan). Yogyakarta: Nuha Medika.

Rahardian, A., Hartuti, P. M., \& Awaludin, A. R. (2018). Penggunaan Aplikasi Geogebra dalam pembelajaran matematika di Sekolah Menengah Pertama. Jurnal Pengabdian kepada Masyarakat, 11-19.

Ridho, N. (2011, 7 27). Model Pembelajara Kooperatif. Cooperative Learning, 1.

Sari, S. f. (2017). Pendidikan Bagi Anak Tunagrahita (Studi Kasus Tunagrahita Sedang di SLB N Purwakarta). Jurnal Penelitian dan $P K M, 220$ 